The Boller Review:
Number 1 $\begin{gathered}\text { A TCU Undergraduate Journal of } \\ \text { Fall } 2016\end{gathered}$

\title{
Fighting for the Moral Cause? State Motivations for Humanitarian
}

\section{Intervention}

by Alayna Sublette

\begin{abstract}
Why do states conduct humanitarian missions in certain states and not in others? This paper evaluates the motivations of states to intervene in other states under the guise of humanitarianism, with a focus on multilateral, military operations. Further, the main factor that this paper addresses is the role that human rights non-governmental organizations (NGOs) play in influencing states to intervene or not intervene, with an emphasis on NGO "naming and shaming." By conducting a comparative case study between the civil conflicts in Kosovo and Rwanda, this paper tests the following hypothesis: the more comprehensivea NGO's "naming and shaming" campaigns are in a particular state in regard to a humanitarian issue, the more likely an outside state will intervene in that target country. Although Kosovo and Rwanda both had "naming and shaming," the differencelies in theamount and substance of the "naming and shaming." This paper argues that Kosovo received more "naming and shaming" at a higher quality, while Rwanda received less "naming and shaming" at a lower quality. Further, this paper argues that these differences in "naming and shaming" contributed to the differing outcomes; Kosovo received substantial international attention, while Rwanda did not.
\end{abstract}

\section{State Selectivity}

As a result of the Rwandan civil conflict and 1994 genocide, between 800,000 and 2,000,000 people were killed in addition to countless other acts of brutal violence (Power 2002, 334 and Musoni 2008). J ust a few years later, from 1998 to 1999, the civil conflict in Kosovo resulted in over 100,000 refugees and 10,000 civilian deaths (Kllokoqi, et al. 2007, 8). Although both of these conflicts were devastating to civilians, only Kosovo received substantial international assistance. 
This discrepancy leads to the question of why states conduct humanitarian missions in certain states and not others. After the Cold War, the world saw a fundamental shift in the way wars are fought, with intrastate warfare taking center stage. The rise of intrastate conflicts introduced new challenges to the international community to proactively address severe human rights violations. One result of the rise of such conflicts has been a reconsideration of state sovereignty. While the preamble of the United Nations Charter begins with the phrase "We the Peoples of the United Nations," suggesting the state may not be absolute, Article 2(7) of the UN Charter establishes that states are sovereign actors with sole authority over issues within their own borders. Nevertheless, as intrastate warfare and human rights violations continue to flourish, the international community and scholars alike cannot help but discuss the dilemma of honoring state sovereignty while also protecting the individual. Although the "should" questions are important and illustrate the value of studying humanitarian intervention, it is equally imperative to answer the "why" and "how" questions. This paper identifies and evaluates the motivations of states to intervene in other states under the veil of humanitarianism, with a focus on multilateral, military operations. Are states' motivations purely humanitarian, or are there other factors at play? What factors determine where states conduct humanitarian missions? Answering these related questions can clarify how the world can expect to see humanitarian missions carried out in the future.

The main factor that this paper addresses in detail is the role that non-state actors, specifically human rights non-governmental organizations (NGOs), play in influencing states to intervene or not to intervene. While some humanitarian interventions have multiple causes, this paper focuses on one specific factor in particular: the effect of human rights NGOs on humanitarian intervention provides significant insight on the role of the state in the international community. This paper 
uses two case studies to describe the interactions of state and non-state actors in order to better explain state decision-making. The following section evaluates the existing literature on humanitarian intervention and sets out the goals of this paper in response to past research.

\section{Previous Research on Humanitarian Intervention}

As the intentions of humanitarian interventions are often inconsistent, a state's decision to intervene or not to intervene is multifaceted. In this paper, humanitarian intervention is defined as a use of military force to protect or maintain human rights in a state undergoing civil conflict. By using this definition, this paper compares the rationale that intervening states profess in alignment with humanitarianism versus the rationale that occurs in practice. Additionally, this paper uses multilateral intervention to describe missions consisting of multiple states.

As is the case in any area of international relations, humanitarian intervention is made up of various actors. These include the intervening states, the international community and/ or institutions, and the states plagued by civil conflict. Examining the interactions of these actors can better explain state motivations that determine whether humanitarian intervention occurs. Previous literature on the topic of humanitarian intervention can be separated into three perspectives: cosmopolitanism/normative, realism/ statism, and internationalism.

\section{Cosmopolitanism/Normative}

Cosmopolitanism is the normative view that the global community is made up of individuals who should be given priority over states when protecting basic human rights (Donnelly 1993, 619). Likewise, international action, including humanitarian 
intervention, is largely dictated by "rights, justice, and morality" (Donnelly 1993, 619). Cosmopolitan scholars such as Robert Pastor argue that human rights violations can potentially upset international order $(1993,656)$. Thus, humanitarian intervention is not only necessary, but justified under humanitarian purposes alone. Scholars such as Alex Bellamy further argue that the principle of Responsibility to Protect (R2P) dictates that "all states have a primary responsibility towards their own citizens" and an obligation "to assist their peers in fulfilling this primary responsibility" whether through military protection or other means $(2008,624)$. In other words, R2P grants legitimacy to humanitarian intervention; humans are given certain rights that the international community has a duty to uphold and protect. Thus, under this principle, humanitarian intervention for solely humanitarian reasons appears to be plausible, at least in theory. Other scholars including Michael Walzer, Mona Fixdal, and Dan Smith attempt to bridge the gap between the moral and strategic/legal implications of humanitarian intervention by using the J ust War doctrine to evaluate humanitarianism $(1998,284)$. Although Walzer points out that a state has a "duty to avoid violence if [it] possibly can" (1977, n.p.), Fixdal and Smith consider some humanitarian missions legitimate by rationalizing the reasons for intervention in the first place (1998, 303). For example, under the J ust War doctrine, "interventions must do more good than harm" and have the right intention (Fixdal and Smith 1998, 303). In this case, the right intention would be to create or maintain a "just peace" by protecting human rights (Fixdal and Smith 1998, 303).

Pastor, Bellamy, Walzer, Fixdal, and Smith all present valid arguments for what constitutes a legitimate humanitarian intervention based on humanitarian reasons alone. It is important to consider the conclusions of these normative arguments as they provide context for this paper. The ideas presented above also allude to how states might choose to act based on what norms "should" motivate 
them versus what factors actually motivate them. This paper raises several questions: What actors set these norms? What influence do these actors have on states? Despite the significance of these questions, scholarship in this perspective fails to evaluate the full range of state motivations. Thus, it is necessary to consider the realist/statist perspective as it relates to humanitarian intervention.

\section{Realism/ Statism}

In this context, statism and realism can be used interchangeably. According to realists such as Hans Morgenthau, self-interest and domestic responsibilities dictate every action of a state (1952, 972). Thus, in the case of humanitarian intervention, a state will act for reasons outside of humanitarianism. Additionally, statists believe that individuals are "objects, rather than subjects" of international politics (Donnelly 1993, 617). In other words, statism is a direct contradiction to the cosmopolitan perspective that individuals are the priority of the international community, while the states are secondary (Donnelly 1993, 617). According to Stephen Gent, a humanitarian motive is not always at the forefront of a state's decision-making process, as states can encounter a free-rider problem when deciding whether to conduct a multilateral humanitarian mission $(2007,1089)$. Gent uses a game theoretic model to illustrate this interaction and to explain that the decisions of intervening states are not isolated as the cosmopolitan perspective would suggest but rather dependent on the actions of other states $(2007,1091)$. Furthermore, Gent believes that future research should focus on political and strategic motivations rather than moral ones (2007, 1101). David Gibbs further elaborates that intervening states will, at certain times, hide under the guise of humanitarianism while their motivations are actually guided by their desire to "project power" over other nations (n.d., 51). He does not, however, discredit 
humanitarian motivations, but rather urges scholars to go beyond a "wishful thinking" analysis (Gibbs n.d., 51).

Morgenthau, Gent, and Gibbs effectively argue that states act out of selfinterest rather than moral obligation alone. Although they illustrate the strategic factors involved in humanitarian intervention including domestic interests and collective action, they fail to fully consider the role of norms and international institutions in the decision-making process. In other words, realism by itself is insufficient; its focus on materialism does not entirely explain why states decide to intervene in certain situations instead of other ones. To further explain the potential importance of the international community as a dynamic actor, the internationalist perspective is necessary.

Internationalism

While cosmopolitanism and statism represent the two competing sides of international relations theory, internationalism lies somewhere in the middle. According to internationalists, while states and individuals are both important to interstate relations, international institutions and practices also play a significant role in influencing the actions of states (Donnelly 1993, 620). Scholars such as Christopher Greenwood discuss the role of international law in humanitarian intervention by stating that international customary law directs the actions of states (1993, 34). Although international law affirms that self-defense is the only legitimate reason for intervening in a sovereign state, the debate is not over what is stated, but rather what is left for interpretation. Contemporary Security Council decisions often reference R2P, an idea that was once a norm, but has since become more practical through the outcome of the 2005 UN World Summit (A/RES/60/ 1) and many UN 
Security Council Resolutions thereafter. ${ }^{1}$ Scholar Thomas Weiss also states that oftentimes, "when humanitarian and strategic interests coincide," humanitarian intervention is then able to occur $(2004,147)$. Furthermore, UN Security Council authorization, in addition to consensus from other countries, can impact a state's decision to intervene (Weiss 2004, 147). There has also been research on the motivations of states to provide humanitarian aid rather than intervention specifically. Scholars A. Cooper Drury, Richard Stuart Olson, and Douglas A. Van Belle argue that state decisions are "made in a political environment-both international and domestic" $(2005,460)$. Thus, state motivation is influenced politically on several different levels according to the internationalist perspective. These arguments raise various questions regarding how states collectively select certain states to intervene in while disregarding others.

Greenwood, Weiss, Drury, Olson, and Van Belle use their knowledge of interstate relations to reconcile the discrepancies between cosmopolitans and realists. Although they discuss interesting points, there is little discussion about multilateral missions versus the more common unilateral humanitarian missions. In order to fill in the gaps of existing literature, this paper emphasizes multilateral missions and the role that various state and non-state actors play in humanitarian intervention. There is certainly a dispute among scholars regarding what factors truly motivate states to intervene. Nevertheless, this paper seeks to find a common ground among the different perspectives.

\footnotetext{
1 UN Security Council Resolutions referencing R2P in 2015- S/ RES/ 2196, S/ RES/ 2217: Central African Republic; S/RES/ 2206, S/ RES/ 2223, S/RES/ 2241, S/RES/ 2252: South Sudan; S/RES/ 2211 : Democratic Republic of the Congo; S/RES/ 2220: Small Arms and Light Weapons; S/RES/ 2227: Mali; S/RES/ 2228: Sudan (Darfur); S/RES/ 2250: Maintenance of International Peace and Security; $\mathrm{S} / \mathrm{RES} / 2254, \mathrm{~S} / \mathrm{RES} / 2258$ : Syria. It must be noted that these resolutions are from the most recent year; R2P is referenced in earlier UN Security Council Resolutions as well.
} 
Three Theories: One-size-fits-all?

The cosmopolitan/ normative, statist/ realist, and internationalist perspectives are crucial in understanding the perception of humanitarian intervention in theory and in reality. Of the three theories, this paper focuses on the internationalist perspective as it provides a solid foundation for evaluating factors such as international norms and institutions, which have received less attention in previous research.

\section{Developing the Internationalist Perspective}

The internationalist perspective is unique in that it recognizes states as more than isolated actors; they are a collection of individuals just as they are a collection of separate entities. In other words, domestic concerns matter, but international norms are also important. This paper evaluates whether international norms and organizations can effectively permeate state borders, rendering both the realist and the cosmopolitan perspectives incomplete in their descriptions of state motivations. Furthermore, this paper explains how the interactions between potential intervening states, the international community, and states plagued by civil conflict collectively affect the ultimate decision to intervene or not to intervene.

In order to account for norms and institutions, this paper uses NGOs to represent the international community. Although there are many factors that can influence a state's decision to intervene under the veil of humanitarianism, NGO "naming and shaming" is one area that has gone largely uncharted. This paper describes the process and effect of "naming and shaming" in several steps: humanitarian norm emergence, norm entrepreneurship, NGO "naming and shaming," and the final transition from norm to state action. 
Humanitarian Norm Emergence

Humanitarian law is outlined in various UN documents, which set out rules to "limit the effects of armed conflicts."2 Although these documents were written when interstate conflicts were the predominant type of war, they remain relevant to the international community as customary law that is reinforced through the general adoption and practice of all states. However, intrastate conflicts prompt new challenges to state sovereignty and the legitimacy of humanitarian intervention. As mentioned earlier, the doctrine of the Responsibility to Protect (R2P) specifically addresses this dilemma and is therefore the focus of this paper's discussion on norm emergence.

R2P began as a norm, but soon emerged as a legitimate principle enumerated at the 2005 UN World Summit. Since 2005, R2P has been cited in many UN Security Council resolutions regarding humanitarian intervention. There are three distinct characteristics of R2P: (1) states have a duty to protect their citizens from genocide, war crimes, ethnic cleansing, and crimes against humanity; (2) the international community has an obligation to provide assistance to states to successfully fulfill this duty; and (3) the international community has a responsibility to protect the population of a state that fails to carry out its primary duty (Bellamy 2010, 143). This paper focuses on the third, most contested pillar of R2P as it strongly alludes to humanitarian intervention. Scholar Alex Bellamy defines norms as "shared expectations of appropriate behavior for actors with a given identity," and although the third pillar of R2P has been mentioned in international documents, its implementation remains a fervent debate in the

\footnotetext{
2 The main UN documents that address humanitarian law include the Geneva Conventions (1949) and the Rome Statute of the International Criminal Court (2002). The above description of humanitarian law is provided by the International Committee of the Red Cross.
} 
international community $(2010,160)$. In other words, it has not received full norm status, perhaps due to its inconsistency and ambiguity in practice. Many states continue to support the previous norm of non-intervention in which a state can only enter another state's borders with the purpose of self-defense. Therefore, states are not always moved to intervene whenever another state has failed to carry out its primary obligation to its citizens. Drawing upon a term coined by Martha Finnemore and Kathryn Sikkink, this paper argues that as a result of this contention, the role of "norm entrepreneurs" becomes an important factor in a state's decision to intervene or not to intervene.

Norm Entrepreneurship and Development

In the case of this paper, the relevant norm entrepreneurs are defined as NGOs that collectively "call attention to issues ... by using language that names, interprets, and dramatizes them" (Finnemore and Sikkink 1998, 897). Furthermore, they use tactics of persuasion to further their goals, which are largely motivated by altruism and empathy (Finnemore and Sikkink 1998, 898). However, before persuasion can take place, scholar Charli Carpenter mentions two necessary steps that must occur: "issue definition" and "issue adoption" (2007, 103). Issue definition takes place when a specialized or domestic NGO identifies a problem in a particular state and offers tangible solutions to address the problem (Carpenter 2007, 103). Issue adoption, which Carpenter stresses as the determinant for a norm to either survive or dissolve, occurs when an issue is embraced by a prominent, international NGO or other "gatekeeper" that can communicate this norm to the international community (Carpenter 2007, 103).

While Finnemore and Sikkink define actors like NGOs as norm entrepreneurs, NGOs are more accurately described as norm developers in the 
context of humanitarian intervention. In other words, NGOs build off of norms, namely R2P, in order to promote policy or address certain issues. This act of norm development requires not only the support of motivated NGOs, but also "organizational platforms," or transnational advocacy networks, that provide a dynamic network of norm sharing and norm generation (Finnemore and Sikkink 1998, 899). Organizational platforms can act as a form of communication between state and non-state actors, which are frequently seen through NGO "naming and shaming" campaigns.

\section{NGO “Naming and Shaming”}

This paper defines "naming and shaming" as an action by a NGO to call attention to atrocities while simultaneously calling for resolution. There is ample literature regarding "naming and shaming" as it relates to human rights law (Hafner-Burton 2008; Lebovic and Voeten 2006; Meernik, et al. 2012; Davis, et al. 2012), but very little in respect to humanitarian law. Additionally, past research primarily focuses on the reactions of the "shamed" states rather than the responses of potential intervening states. In order to apply this idea of "naming and shaming" to a different scenario, this paper focuses on NGOs and the effect that their actions have on states to intervene or not to intervene in a state undergoing civil conflict.

Recently, scholars Amanda Murdie and Dursun Peksen have explored a similar topic of "naming and shaming" as it relates to humanitarian intervention (2013). In their most current article, they conducted a large-N study to measure whether human rights organizations affect state decisions to intervene for humanitarian reasons (Murdie and Peksen 2013). They found that "naming and shaming" by NGOs does, in fact, increase the likelihood of military intervention, which they label as the "Amnesty International Effect" (Murdie and Peksen 2013, 5). 
Although Murdie and Peksen produce some important results, this paper aims to further unpack the relationship between NGOs and states as well as to answer "why" this relationship exists. Furthermore, this paper uses a more descriptive methodology through a comparative case study to illustrate the causal mechanisms behind the relationship between NGOs, states, and humanitarian intervention.

Drawing from both the boomerang and spiral models created by scholars Risse, Ropp, Sikkink, and Keck, this paper situates "naming and shaming" campaigns in a similar fashion to describe the various interactions between international and domestic actors. In the boomerang model, Keck and Sikkink describe an interaction in which the host country's domestic NGOs push for humanitarian intervention (Keck and Sikkink 1998, 13). Similarly, the spiral model involves a series of "boomerang throws" originating from domestic NGOs that are emphasized through transnational NGOs and state governments (Risse, Ropp, and Sikkink 1999, 3 and 18). Risse, Ropp, and Sikkink contend that the spiral model "operationalizes ... norm socialization" in each of the steps, which include adaptation, arguing, and institutionalization (1999, 19). In this case, the "arguing" phase can be represented through "naming and shaming" (Risse, Ropp, Sikkink 1999, 19). In other words, domestic and transnational NGOs use information to create pressures on potential intervening states and shamed states to address human rights violations. By calling attention to human rights abuses in war-torn states, NGOs attempt to guide international conversation to further their moral agenda of upholding and protecting universal human rights. Oftentimes, these pressures take the form of "naming and shaming" campaigns, which can be 
separated into four types: information politics, symbolic politics, leverage politics, and accountability politics (Keck and Sikkink 1998, 16). ${ }^{3}$

According to the boomerang model, NGOs in potential intervening states and states undergoing civil conflict create pressures from the bottom and the top, or from the domestic and international level, in order to begin the mobilization process (Risse, Ropp, and Sikkink 1999, 5). The four aspects of "naming and shaming" represent this boomerang action. Information and symbolic politics incite reactions from the domestic public, while leverage and accountability politics trigger reactions from the international public and the states themselves. This paper argues that the ability and extent of NGOs to carry out these attributes of "naming and shaming" can directly affect the "tipping point," or decision making, of states to intervene under humanitarian purposes. Additionally, the ability of NGOs to promote the norm of R2P through these aspects of "naming and shaming" can affect the state's acceptance of these actions. However, the effectiveness of NGOs to "name and shame" is not enough to explain the relationship between NGOs and states; the attributes of the states themselves play a crucial role in the degree to which "naming and shaming" actually influences states. Therefore, this paper must turn to the next step in the decision making process: norm to state action.

Norm to State Action

"Norm to state action," in the case of this paper, refers to a state's decision to intervene. Finnemore and Sikkink discuss the various motivations of states, which include legitimacy, reputation, and esteem $(1998,898)$. All three of these

\footnotetext{
${ }^{3}$ Information politics refers to "the ability to quickly and credibly generate politically usable information and use it to where it will have the most impact." Symbolic politics refers to "the ability to call upon symbols, actions, or stories that make sense of a situation for an audience that is frequently far away." Leverage politics refers to "the ability to call upon powerful actors to affect a situation where weaker members are unlikely to have influence." Accountability politics is "the ability to hold powerful actors to their previously stated policies or principles."
} 
motivations suggest that states are conscious of how they are perceived by their citizens and other states. This paper focuses on the same concept, with an emphasis on public opinion and international reputation. If the internationalist perspective holds true, these motivations are heavily influenced by norms and the actions of NGOs. Additionally, if there is more discussion about human rights abuses through information and symbolic politics, complete ignorance of certain atrocities is impossible; states will experience pressures from NGOs and individuals alike. As NGOs move through the "naming and shaming" campaign process by instituting leverage and accountability politics, states will want to preserve their international status. Additionally, if a state has set a past precedent of humanitarian intervention, "naming and shaming" will have a greater effect on that state's decision than if the opposite is true. In other words, the state may feel a sense of obligation to intervene not only for humanitarian purposes, but also to uphold a certain status.

Furthermore, a state might feel the pressure to maintain a reputation to prevent or at least discourage future atrocities. Conversely, if a state is not a dynamic actor on the world stage, it might be less affected by "naming and shaming" campaigns. By using the following hypothesis, this paper posits that the NGOs' ability to set the agenda by "naming and shaming" a certain state has a significant influence on a state's choice to intervene:

Hy pothesis: The more comprehensive a NGO's "naming and shaming" campaigns are in a particular state in regards to a humanitarian issue, the more likely an outside state will intervene in that target country.

There are certain conditions that constrain this hypothesis. As mentioned above, "naming and shaming" might have the strongest effect on states that have a prominent reputation in the international community. Therefore, this paper focuses on these states in particular. Another condition to consider is the type of NGO; 
certain NGOs have more authority than others. Similar to states, their reputation is a factor. Lastly, in order to account for a possible reciprocal relationship between NGOs and states (states influencing NGOs and NGOs influencing states), this paper evaluates NGOs that are most independent from government control and do not shy away from critiquing powerful states.

The findings of this paper could answer multiple questions. In terms of direct results, it could identify one important factor that motivates a state to intervene. This research could also evaluate the strength of the internationalist argument. Additionally, if this paper can identify who helps set the agenda in regards to humanitarian intervention, it could contribute to the discussion of future foreign policy decisions.

\section{Research Design}

As mentioned earlier, previous research regarding the relationship between "naming and shaming” campaigns and state motivations for intervention only confirm the existence of the relationship through a large- $\mathrm{N}$ study rather than explain why the relationship exists (Murdie and Peksen 2013). In order to fill in the gap in methodology, this paper conducts a hypothesis-testing, comparative case study between the civil conflicts in Kosovo and Rwanda. The Kosovo conflict is an example in which NGO "naming and shaming" campaigns did occur and states subsequently intervened. Conversely, the Rwanda conflict is an example in which "naming and shaming" campaigns took place, but with very little international mobilization. Thus, by comparing these two cases that began with similar conditions in regards to NGO participation, but produced different results, this paper identifies the specific factors that led to these opposing outcomes.

The cases of Kosovo and Rwanda are important to this study for several reasons. Not only are the conflicts relatively close in terms of time period, ranging 
from the 1970s to the 1990s, the characteristics of the conflicts are also similar; the Serbs tried to eradicate the Kosovars from Yugoslavia, while the Hutu tried to wipe out the Tutsi from Rwanda (Adelman 1999, 5). Both the Kosovars and the Tutsi also represented minority groups (Kllokoqi, et al. 2007, 7 and Power 2002, 331). Additionally, both countries had similar political systems (Adelman 1999, 5). Thus, the general environment of each conflict can be held as a constant. NGOs fought for intervention in both cases, but only one case, Kosovo, elicited a strong reaction from the international community to intervene. Additionally, this comparative case study targets the relationship between NGOs and states before and during the conflicts in Kosovo and Rwanda. In other words, the parameters of this study focus on the transition from pre-intervention to intervention, or lack thereof.

Dependent Variable: Multilateral Intervention

As stated previously, the hypothesis for this paper is The more comprehensivea NGO's "naming and shaming" campaigns are in a particular state in regards to a humanitarian issue, the more likely an outside state will intervene in that target country. Thus, the dependent variable in this study is the presence or absence of humanitarian intervention in a given country. Specifically, it is the presence or absence of a multilateral military operation. For simplicity, this paper focuses on the US when examining multilateral missions as the US was the dominant actor in both cases. Multilateral missions are crucial to this paper as they better describe state decision making on an international level, thus evaluating the validity of the internationalist argument. As the world continues to become more interconnected, instances of multilateral missions are also likely to increase. Independent Variable: NGO "Naming and Shaming"

The independent variable in this study is NGO "naming and shaming." As mentioned earlier, this paper studies the effect of a prominent, credible NGO's 
actions on a state's decision making. Thus, this paper uses Amnesty International (AI) and Human Rights Watch (HRW), as they were active in both Kosovo and Rwanda. Although AI and HRW are independent from government, they work with smaller, local NGOs that could affect the overall success of "naming and shaming" campaigns. In order to specify "naming and shaming” in realistic terms, this paper uses the four types of persuasion coined by scholars Keck and Sikkink: information politics, symbolic politics, leverage politics, and accountability politics $(1998,16)$ :

I. Information politics: Information politics is the action of a NGO to release valuable information regarding human rights violations to the public. This paper tests this type of persuasion by describing the annual reports published by AI and HRW as well as measuring the amount of news reports that mention AI, HRW, "human rights," and the conflict in question through the New York Times.

II. Symbolic politics: Symbolic politics is a NGO's ability to “call upon symbols, actions, or stories" that can generate connections with a public that is mentally or geographically removed from the situation. This paper tests this type by measuring the number of CNN broadcast transcripts that mention AI, HRW, "human rights," and the conflict in question. III. Leverage politics: Leverage politics is a NGO’s ability to “call upon powerful actors to affect a situation where weaker members are unlikely to have influence." This paper tests this type by describing the nature of the appeals AI and HRW make to the US.

IV. Accountability politics: Accountability politics refers to a NGO's ability to "hold powerful actors to their previously stated policies or principles." This paper tests this type by analyzing the kind of language AI and HRW use towards a state's governing body. 
This paper employs a process-tracing method to gather this information as a chain of events. AI and HRW "naming and shaming" campaigns grow more active as they move through the various phases of persuasion: information politics, symbolic politics, leverage politics, and accountability politics. As they carry out the various phases, AI and HRW affect two variables: public opinion and state reputation. In their large-N study, scholars Murdie and Peksen also account for the "intensity" of "naming and shaming" campaigns (2013). This paper addresses "naming and shaming" intensity in greater depth through a comparative case study of Kosovo and Rwanda.

Although Rwanda and Kosovo both had "naming and shaming," the difference lies in the amount and substance of the "naming and shaming." This paper argues that Rwanda received less "naming and shaming" at a lower quality, while Kosovo received more "naming and shaming" at a higher quality (instituting all four types of persuasion), thus contributing to the differing outcomes. Furthermore, this paper uses a similar hypothesis constructed by Murdie and Peksen as a guide to evaluate what attributes of "naming and shaming" and state preferences must hold true for the relationship between NGOs and states to be significant.

Intervening Variable 1: Public Opinion

The first intervening variable in this causal relationship between "naming and shaming" and the presence/ absence of humanitarian intervention is public opinion. Public opinion is directly influenced by the first two types of persuasion, information and symbolic politics, as both are publicly accessible. This study measures public 
opinion in favor of/ against humanitarian intervention by using US Gallup Polls that address atrocities overseas. ${ }^{4}$

Intervening Variable 2: Reputation/International Involvement in the Past

The second intervening variable is state reputation, which is directly influenced by the last two types of persuasion: leverage and accountability politics. Reputation is a good indicator of whether a state will intervene or not, as it measures a pattern of recurring actions, in this case intervention, that stays relatively constant. In other words, a state that has a reputation of intervening, will be more likely to intervene in the future than a state that does not. Furthermore, reputation is not measured as "good" or "bad," but rather measured by whether a particular state has a reputation of intervening under the guise of humanitarianism.

Tying it all together

This paper seeks to measure not only the amount of "naming and shaming" that takes place, but also which specific tactics of "naming and shaming" are used by $\mathrm{AI}$ and HRW. Therefore, this paper analyzes the action rather than the existence of the action alone. Additionally, by specifically measuring a state's reputation in regards to humanitarian intervention and the type of public opinion (either in favor or against intervention), this paper accounts for the intervening variables that can ultimately explain the dependent variable: multilateral intervention.

As mentioned above, this paper uses a process-tracing method to analyze the relationship between NGOs, states, and humanitarian intervention. In order to compare the cases in Kosovo and Rwanda, this paper first discusses the context in which these cases took place; the Kosovo conflict took place from 1998-1999, while the Rwanda conflict transpired from 1993-1994, approximately. However, these

\footnotetext{
4 I analyze all of the Gallup Polls available that mention the conflict (before and during).
} 
dates simply represent the peak of each conflict; NGO "naming and shaming" campaigns were present earlier than the dates above. This paper then outlines the nature of the problem and the subsequent conflict in each case. After describing the crises, this paper analyzes NGO activity and communication with states through the various types of "naming and shaming." Finally, this paper evaluates the decisions to intervene or not to intervene.

\section{Expected Results}

The factors that motivate states to intervene for humanitarian purposes are certainly complex. However, this paper uses one factor, NGO "naming and shaming," to make several conclusions about various state motivations in the international arena including the role of reputation and public opinion. As the world continues to become more interconnected, the relationships between citizens, states, international organizations, and non-state actors become vital tools in interpreting multilateral decisions and outcomes. By describing these relationships, this paper expands upon the internationalist perspective regarding the role of norms and the international community. Furthermore, the debate about whether to endorse R2P's humanitarian intervention or non-intervention is relevant today. This paper illustrates this conundrum through a detailed look at NGO "naming and shaming." Furthermore, by describing the actions of NGOs, this paper can evaluate which actors truly help set the agenda for humanitarian intervention. By recognizing the role that NGOs and international norms play in humanitarian intervention, this paper also speaks volumes for predicting and interpreting foreign policy decisions; strategic interests matter, but international practices also play a part.

By using a comparative case study and process-tracing methodology, this paper's expected findings are that states (Kosovo) in which NGOs are comprehensive in their "naming and shaming" campaigns are more likely to experience 
humanitarian intervention than states (Rwanda) in which NGO "naming and shaming" is not as intense or comprehensive. In other words, this paper posits that NGO "naming and shaming" activates a state's decision to intervene by targeting a state's domestic and international reputation. Thus, potential intervening states are more likely to intervene if they value international reputation and public opinion. Humanitarian interventions will no doubt remain inconsistent, but the role of NGO "naming and shaming" is one factor that can explain these inconsistencies and provide a newfound perspective on the role of the state in international relations.

\section{Case Study: Kosovo}

Brief History

After being occupied by Serbia in 1912, Kosovo was largely viewed as an "ethnically divided society," as the Albanians and the Serbs remained relatively separate from each other (Kllokoqi, et al. 2007, 5). After Slobodan Milosevic gained power, the Serbian government began "aggressive apartheid practices" against the Albanians in Kosova (Kllokoqi, et al. 2007, 6). From 1989 to 1990, there were frequent conflicts between the Serbian police and the Albanian population, resulting in many casualties (Kllokoqi, et al. 2007, 7). The main factors that led to these crises were the differences in language and the strong nationalist sentiments from both sides (Kllokoqi, et al. 2007, 6). On February 28, 1998, the Serbian army and police conducted a military campaign against the Albanians in Drenica villages (Kllokoqi, et al. 2007, 7). As a result, the Kosovo Liberation Army (KLA) fought back (Kllokoqi, et al. 2007, 7). On March 24, 1999, the North Atlantic Treaty Organization (NATO) carried out air strikes against Yugoslavia (Kllokoqi, et al. 2007, 20). Nevertheless, the conflict between the Serbs and the KLA lasted until J une of 1999 with a final death toll of more than 10,000 civilians (Kllokoqi, et al. 2007, 8). 
NGO Response

Several NGOs were active during the Kosovo conflict: Sant'Egidio, Amnesty International (AI), Human Rights Watch (HRW), Mercy Corps, Unrepresented Nations and Peoples Organizations (UNPO), the Transnational Foundation in Sweden, the Helsinki Citizens Assembly, and Minnesota Advocates for Human Rights (Kllokoqi, et al. 2007, 14). ${ }^{5}$ This paper primarily focuses on the responses from $\mathrm{AI}$ and HRW as they are highly respected by the international community and provide the "issue adoption" stage that Kosovo required.

It must be noted that $\mathrm{AI}$ and HRW differ in their approaches to human rights violations. AI focuses heavily on unfair trials and wrongful arrests, while HRW's mission is broader, encompassing various aspects of human rights (Amnesty International 2016 and Human Rights Watch 2016). Further, HRW uses interviews as the cornerstone to its research, while AI focuses predominantly on campaigns and demonstrations (Human Rights Watch 2016 and Amnesty International 2016). Amnesty International's Response

AI started reporting cases of unjust arrests and harmful treatment of detainees in Kosovo beginning in the 1980s (AI Reports 1981-1990). In the years leading up to 1990, ethnic tensions and nationalist sentiments continued to increase in Kosovo, with arrests reaching up to 4,500 people in 1989 (AI Report 1990, 263). A large number of those arrested were ethnic Albanians (AI Report 1990, 263). Many prisoners claimed to have been "brutally beaten" by staff and were often arrested after participating in peaceful protests and demonstrations (AI Report 1990, 263).

\footnotetext{
${ }^{5} \mathrm{HRW}$ was founded as Helsinki Watch in 1978 as a result of the Helsinki Accords (Human Rights Watch 2016). Thus, HRW and Helsinki Watch are used interchangeably in this paper.
} 
In response to these arrests and beatings, AI issued statements of concern and attended trials (AI Reports 1981-1990).

While the 1980s consisted of early unrest, the 1990s were defined by even greater violence. In its report from 1991, AI stated that Serbia's new constitution in 1990 had removed much of Kosovo's autonomy (252). Additionally, AI reports from 1991 to 1998 cited frequent acts of police brutality in Kosovo. After the violent conflicts in the late 1990s, AI published reports referencing the growing number of displaced persons from Kosovo (AI Reports 1999 and 2000). During the 1990s, AI called for immediate investigations from the Serbian authorities regarding police brutality (AI Reports 1992 and 1993), communicated with the UN Commission on Human Rights to express its concerns (AI Report 1994, 321), and issued several reports specifically outlining human rights abuses in Kosovo, including Yugoslavia: Ethnic Albanians--Trial by truncheon (AI Report 1995). During 1998, AI's commitment to Kosovo appeared to increase; members and supporters of AI held public demonstrations around the globe, called on the international community to "introduce immediate, effective, independent human rights monitoring in the province," and urged Yugoslav authorities to stop "indiscriminate attacks" and "guarantee the safety and wellbeing of ethnic Albanian detainees" (AI Report 1999, 35).

In short, AI was able to collect and disperse valuable information regarding human rights violations in Kosovo. The language used in AI reports did vary; in the early 1980s, calls to action appeared to be more passive, simply expressing concern, but as the conflicts became more violent, AI's rhetoric grew more forceful. Human Rights Watch's Response

HRW is a prominent international human rights organization with missions around the world (Human Rights Watch 2016). Similar to AI, HRW also releases 
annual human rights reports. All of HRW's annual reports on Kosovo closely mirrored the reports made by AI; the reports cited the use of torture and police brutality by the Serbs (HRW Reports 1989 and 1990), described the wrongful arrests and job terminations of ethnic Albanians living in Kosovo (HRW Reports 1989, 1992, 1997), and outlined the violence between the KLA and the Serbs (HRW Reports 1999 and 2000). ${ }^{6}$

However, HRW is unique from AI; in most reports during this time period, HRW also included a US policy section with evaluations and recommendations for the future. In HRW Report 1989, HRW stated that Kosovo should be "granted greater autonomy" and suggested that the US open a consulate in Kosovo. HRW also had specific staff members reporting on US policy (Kenneth Roth) and/ or communicating directly with the US Administration and Congress regarding Yugoslavia (Holly Burkhalter) (HRW Report 1989). Additionally, HRW claims that a "major aspect of [its] work" is to influence the US to "use its power, purse, and prestige to promote human rights worldwide" and, as such, has published 2 annual reports since the early 1980s "devoted entirely to United States policy" (HRW Report 1989). ${ }^{7}$ Early on, HRW was critical of the lack of US involvement in Yugoslavia, calling its efforts "sluggish and inconsistent" (HRW Report 1993), but did note that some members of Congress "took an interest in Yugoslavia and brought considerable publicity to human rights issues" (HRW Report 1990). ${ }^{8} \mathrm{HRW}$ also strongly encouraged the US to "take a more active role in condemning human rights

\footnotetext{
${ }^{6}$ HRW reports prior to 1989 were not available.

${ }^{7}$ HRW also appealed to the European Community to pass economic sanctions on Yugoslavia (HRW Reports 1990 and 1992), but this paper focuses primarily on the US.

${ }^{8}$ HRW Report 1990 cited that "public statements by Senator Dole while he and other members of a US congressional delegation were in Kosovo in September received wide press attention in Yugoslavia and elsewhere. See Reuters, September 7, 1990."
} 
violations" (HRW Report 1992) and to "take the lead at the United Nations in seeking action” (HRW Report 1993). Through these appeals, HRW displayed examples of both leverage and accountability politics. HRW's response was fairly consistent throughout the Kosovo conflict; HRW published reports (HRW Reports 1989-2000), wrote letters to local officials (HRW Reports 1992 and 1993), testified before US Congress (HRW Report 1993), and published op-eds/ newsletters via the New York Times (HRW Report 1990).9

HRW regularly works with domestic NGOs and other organizations when writing reports and interviewing victims (Human Rights Watch 2016). Further, domestic NGOs often provide valuable information regarding the cultural undertones of the conflict in question. The situation in Kosovo was no exception. In its reports, HRW frequently referenced a domestic human rights organization called the Council for the Defense of Human Rights and Freedoms in Kosovo that “[monitored] abuses” (HRW Reports 1992, 1993, 1998). International human rights NGOs like HRW act as a "gatekeeper" that communicate information regarding human rights violations to the rest of the world by drawing on the knowledge and expertise of local NGOs. In other words, the Council for the Defense of Human Rights and Freedoms in Kosovo defined the problems taking place in Kosovo, while HRW adopted those issues to garner international attention.

Media Response

Both AI and HRW used the media as a means to spread their message regarding Kosovo (Amnesty International and Human Rights Watch). Although the

\footnotetext{
9 "An op-ed article by Helsinki Watch on ferment in Yugoslavia appeared in the New York Times on November 10, and a newsletter on recent developments in Yugoslavia was released in December. See "Truth is a Casualty of Partisan Yugoslav Press," New York Times, September 13, 1990. See J eri Laber and Kenneth Anderson, "Why Keep Yugoslavia One Country?" New York Times, November 10, 1990."
} 
media can act as an independent actor, AI and HRW provide valuable information and expertise regarding human rights violations. Additionally, AI and HRW are credible sources that the media often cites to support its claims. This paper looks at two media outlets: the New York Times and CNN. ${ }^{10}$

There were 1,495 New York Times articles that mentioned Kosovo from J anuary 1, 1986 to March 23, 1999. ${ }^{11}$ The amount of coverage varied throughout the years:

\begin{tabular}{|l|l|l|l|l|l|l|l|l|l|l|l|l|l|l|}
\hline Year & 198 & 198 & 198 & 198 & 199 & 199 & 199 & 199 & 199 & 199 & 199 & 199 & 199 & 199 \\
& 6 & 7 & 8 & 9 & 0 & 1 & 2 & 3 & 4 & 5 & 6 & 7 & 8 & 9 \\
\hline $\begin{array}{l}\text { Mentio } \\
\text { ns }\end{array}$ & 7 & 19 & 40 & 39 & 79 & 56 & 72 & 96 & 24 & 31 & 19 & 39 & 64 & 334 \\
\hline
\end{tabular}

Coverage of Kosovo closely mirrored the stages of the conflict; most coverage took place in 1990, 1993, 1998, and 1999, which correlates with what happened in reality. In 1990, conflicts between the Serbs and Albanians were becoming more violent (Kllokoqi, et al. 2007, 7). In 1993, conflicts in various Yugoslav provinces, including Bosnia, were reaching a point that required international attention; for example, an international arms embargo had just been imposed on Bosnia (Lampe 2015). In 1998 and 1999, the US and other NATO states became heavily involved in negotiations with the Serbs and the Albanians (Auerswald 2000, 174). The content of the articles varied; some articles addressed human rights violations specifically

\footnotetext{
10 The New York Times and CNN are highly regarded as credible sources of information, which is why they were used for this study. Nevertheless, it must be noted that there were many newspapers and networks that could have also played a role in information/ symbolic politics and guided the conversation about Kosovo in the US.

${ }^{11}$ Data was retrieved from LexisNexis. Although "naming and shaming" took place as early as 1980, Lexis Nexis only has data from 1986 to the present. I chose the end date as March 23, 1999 because that was the day before the first NATO air strikes.
} 
(294 mentions of "human rights"), while others discussed the various peace talks between the parties in the Kosovo conflict. In all cases, however, Kosovo was mentioned in some capacity, which made the topic salient in the US, contributing to information politics. Furthermore, out of these 1,495 cases, there were 7 references of AI and 25 references of HRW. 1 AI mention and $3 \mathrm{HRW}$ mentions were letters to the editor written by high-ranking members from these organizations.

There were 1,388 mentions of Kosovo from CNN broadcast transcripts from January 1, 1986 to March 23, 1999.12

\begin{tabular}{|l|l|l|l|l|l|l|l|l|l|l|l|l|l|l|}
\hline Year & 198 & 198 & 198 & 198 & 199 & 199 & 199 & 199 & 199 & 199 & 199 & 199 & 199 & 199 \\
& 6 & 7 & 8 & 9 & 0 & 1 & 2 & 3 & 4 & 5 & 6 & 7 & 8 & 9 \\
\hline $\begin{array}{l}\text { Mentio } \\
\text { ns }\end{array}$ & 0 & 0 & 0 & 0 & 1 & 0 & 44 & 98 & 23 & 11 & 3 & 8 & 60 & 591 \\
\hline
\end{tabular}

Similar to the New York Times articles, the CNN transcripts closely mirrored the escalation of the conflict in Kosovo in 1998 and 1999. Furthermore, there was fairly sustained coverage from 1992 to 1999. The CNN transcripts varied in content with 139 transcripts mentioning "human rights" explicitly and the rest of the transcripts focusing on violence more broadly and/ or peace and security talks. There were two mentions of AI and one mention of HRW. CNN brought the topic of Kosovo to Americans' television screens, contributing to symbolic politics and appealing to people's emotions.

International Response

On March 24, 1999, NATO conducted air strikes against Yugoslavia, with "the desire to stop crimes against humanity ... clearly among its major goals." (Kllokoqi,

12 Data was also retrieved from LexisNexis. 
et al. 2007, 20). Although the motivations of the international community during the Kosovo conflict were mixed and at times based on self-interest, the rhetoric of the various states closely mirrors the sentiments of NGOs like AI and HRW, which suggests that states were in fact influenced by "naming and shaming" techniques. United States Response

The US was one of the primary actors involved in the NATO intervention in Kosovo (Auerswald 2000). At the time, the US was also a prominent actor on the world stage with a reputation for intervention. Human rights rhetoric was present throughout US institutions, whether it was from Congress, the US Department of State, or the president himself. Further, there were also several instances in which $\mathrm{AI}$ and HRW were directly referenced.

In a speech regarding the Kosovo conflict, former US Senator Alfonse D'Amato stated that "Amnesty International, Helsinki Watch, and the U.S. State Department have all documented extensive human rights abuses in Kosovo ...the most basic rights have been violated by the Serbians in their effort to control Kosovo," and that "these actions deserve a response from the United States" (Yugoslavia, Senate, J une 28, 1990). Additionally, former US Congressman Benjamin Gilman stated that “Amnesty International's report for 1990 [cited] a significant number of human rights practices in Yugoslavia that clearly violate internationally accepted human rights standards..." (Regarding Albanian Minorities in Yugoslavia, House of Representatives, October 22, 1990). In one of his remarks, US Congressman Eliot Engel mentioned that "Amnesty International and Human Rights Watch ... and others [documented] worsening humanitarian conditions," and that he "strongly [believed] that the United States must ... speak out more vociferously against the silent extension of ethnic cleansing to Kosova" (The Kosova Peace, Democracy, and Human Rights Act of 1995-Extensions of Remarks, March 
31, 1995). In terms of legislation, several bills before and during the NATO air strikes strongly condemned the human rights violations taking place in Kosovo, turning rhetoric into action. US Congress "[urged] the Government of Yugoslavia to: (1) assure that further violence [did] not occur in Kosovo; and (2) [observed] its obligations under the Helsinki Final Act and the United Nations Declaration of Human Rights to assure full protection of the rights of national groups in Yugoslavia" (S.1347, 1989), called for "an end to the violent repression of the people of Kosovo" (S.Con.Res.85, 1998), and "[expressed] the sense of Congress regarding the need for vigorous prosecution of war crimes, genocide, and crimes against humanity in the former Republic of Yugoslavia" (S.Con.Res.33, 1999). Overall, US Congress appeared to be especially vocal about the human rights violations in Kosovo.

During the Kosovo conflict, statements from the US Department of State illustrated how the US portrayed itself to the rest of the world. As the conflict was growing in the 1990s, the US Department of State made various statements that referred to the situation in Kosovo as "extremely grave" (Auerswald 2000, 51), "emphasized the understanding of the American people and government for the difficult circumstances of the Albanian people of Kosovo" (Auerswald 2000, 63), and highlighted the "growing interest of the world community in the situation in Kosovo" (Auerswald 2000, 63). Although former Secretary of State Madeleine Albright welcomed a "non-violent approach" (Auerswald 2000, 174) to the Kosovo conflict, she also stressed the importance of reacting with "firmness, unity, and speed" (Auerswald 2000, 118). The State Department's initial approach was diplomacy through negotiation, which soon turned into humanitarian aid, and finally ended with military intervention through NATO (Auerswald 2000, 235). Throughout the 
conflict, the US dominated the international conversation, with NATO as its ultimate tool.

In a statement to President Milosevic in 1992, US President George H. W. Bush made it clear that the US was "prepared to employ military force against Serbians in Kosovo and in Serbia proper" if necessary (Auerswald 2000, 65). Years later, the night before the NATO bombings, US President Bill Clinton addressed Americans regarding the crisis in Kosovo: "you've got to decide, my fellow Americans, if you agree with me that in the 21st century, that America, as the world's superpower, ought to be standing up against ethnic cleansing if we have the means to do it and we have allies who will help us do it in their neighborhood" (J ackson 2006, 149). Furthermore, Clinton stated that "the dangers of acting are far outweighed by the dangers of not acting-dangers to defenseless people and to our national interests ...America has a responsibility to stand with our allies when they are trying to save innocent lives and preserve peace, freedom and stability in Europe" (J ackson 2006, 147). The president of the United States represents an important link between the American people and world events; Clinton certainly catered to American ideals in his speeches regarding Kosovo.

Not only did the US view itself as a world power, but the US also felt obligated to intervene in order to stand by its allies and uphold the moral cause. Therefore, the US chose to intervene in order to preserve its reputation as a dominant international actor and prevent future atrocities from occurring.

US Public Opinion

US public opinion varied during the Kosovo conflict. On J une 24, 1999, a Gallup poll found that $60 \%$ of Americans believed that the US should "maintain" a prominent, dynamic role in international relations, 69\% “[approved] of US troops serving under NATO command," and 66\% were in favor of the US reacting to human 
rights abuses with "military force” (“Kosovo Intervention Hasn’t Shaken”). However, according to another Gallup poll published in March 24, 1999, only one-third of Americans "[followed] the situation closely" ("Americans Hesitant"). Perhaps the US cares more about international prestige than domestic support. Still, in the same poll, $58 \%$ of Americans believed that the US had a "moral obligation to help keep the peace in Kosovo" ("Americans Hesitant").

Success of NGO "Naming and Shaming"

All types of NGO "naming and shaming" were present during the Kosovo conflict. However, the size and scope of each type varied.

Information and Symbolic Politics

Information politics were comprehensive and sustained throughout the Kosovo conflict. AI and HRW consistently published annual reports summarizing human rights violations in Kosovo prior to NATO intervention. HRW also worked with domestic NGOs in Kosovo, giving HRW a deeper level of knowledge of the human rights abuses in the area. Additionally, the New York Times articles that mentioned Kosovo were abundant, with several references to AI and HRW. The dispersal of this information represented an acknowledgment of the severe human rights violations present in Kosovo. Additionally, the accessibility of this information helped the conversation about Kosovo remain relevant.

Symbolic politics came in the form of CNN news segments. Although CNN did not reference AI or HRW nearly as often as the New York Times, the network did mention Kosovo frequently, especially in the 1990s. While the New York Times represents a more passive medium for spreading information (not everyone is going to actively read the news every day), CNN is more interactive; American families watched and listened to people discuss the conflict, forcing them to grapple with, or at least consider, the situation in Kosovo. 
Leverage and Accountability Politics

In reality, leverage and accountability politics are largely intertwined in the case of the US. Leverage politics was present, but to a lesser degree than the previous two types of persuasion. HRW called on the US to be proactive in addressing the crisis in Kosovo; it included a US policy section in its annual reports and testified before US Congress. HRW also referenced past international failures to facilitate a response from the US. For example, in 1998 Fred Abrahams, a HRW researcher, testified to the Commission on Security and Cooperation in Europe-US Helsinki Commission stating that "we must learn from past mistakes ... in 1991 the West watched as Bosnia burned. Since Dayton, the U.S. has simply hoped that the Kosovo problem would melt away under the literary heat of passive nonviolence. Now is a moment to take preemptive steps before the downward cycle of violence gains too much momentum" (Repression and Violence in Kosovo, March 18, 1998). This appeal was significant because, during this time, the US did not want to appear weak or incompetent-especially when past situations had been particularly embarrassing (i.e. Bosnia and Rwanda). Finally, accountability politics was employed the least often. However, HRW did mention that it focused on the US because of "its power, purse, and prestige," which suggests that HRW strategically targeted the US in order to elicit the best response (HRW Report 1989).

\section{Result: United States Response}

Through the rhetoric of various members of Congress, the State Department, and the president, the US response closely mirrored the sentiments of AI and HRW, with a couple of direct references to AI and HRW research. Through his speeches, President Clinton strongly endorsed the notion that the US is obligated to intervene when human rights are being violated. Perhaps AI and HRW focused heavily on information politics because international response was inevitable; instability in the 
region had been growing and past failures to intervene reminded countries like the US of the repercussions of non-intervention. Nevertheless, information regarding Kosovo was sustained for nearly two decades, which suggests an effort by AI and HRW to keep Kosovo on the agenda. Thus, NGO "naming and shaming" was comprehensive for this specific situation.

\section{Case Study: Rwanda}

Brief History

On April 6, 1994, a plane with Rwandan PresidentJ uvenal Habyarimana and Burundian President Cyprien Ntaryamira was shot down (Power 2002, 329). Soon after, armed Hutu filled the streets of Kigali, killing all moderate Hutu politicians and Prime Minister Agathe Uwilingiyimana (Power 2002, 331). Additionally, ten Belgians from the UN Assistance Mission for Rwanda (UNAMIR) were brutally killed (Power 2002, 332), and the Tutsi were hunted down systematically and purposefully (Power 2002, 333). Before the attacks started, the Hutu and the Tutsi coexisted and some intermarried (Power 2002, 334). These attacks tore apart families and friends (Power 2002, 334). Over a 100-day period, between 800,000 and 2,000,000 Tutsi and moderate Hutu were killed (Power 2002, 334 and Musoni 2008). In July 1994, the Rwandan Patriotic Front (RPF) ended the genocide by taking control of the Rwandan government (HRW Report 1995). Nevertheless, the tragedies continued; thousands of Rwandans who fled the country "died of disease, starvation, and lack of water" (HRW Report 1995). ${ }^{13}$ And the world was silent.

\footnotetext{
${ }^{13} \mathrm{RPF}$ was dominated by the Tutsi.
} 


\section{NGO Response}

Along with Amnesty International (AI) and Human Rights Watch (HRW) ${ }^{14}$, there were a handful of domestic NGOs that monitored the human rights violations in Rwanda., which are discussed in more detail below.

Amnesty International's Response

AI did not report any ethnic unrest between the Hutu and the Tutsi until its 1988 Report, which cited tensions between the Hutu and the Tutsi in Burundi, a state that shares a border with Rwanda (26). In its 1989 Report, AI described a "massacre by Tutsi-dominated troops of thousands of unarmed Hutu" in 1988 (10). As a result, thousands of Hutu escaped to Rwanda, Tanzania, and Zaire (AI Report 1989, 10). Some reports found that 5,000 Hutu and Tutsi were killed, but other reports claimed that 20,000 people were killed (AI Report 1989, 38). AI Report 1990 recounted more violence among the Hutu and the Tutsi in Burundi (5). In October 1990, a group of armed "Rwandese exiles, mostly members of the Tutsi ...invaded northeast Rwanda from Uganda" to attempt to take over the government (AI Report 1991, 193). As a result, many civilians caught between the rebel groups and the government were killed (AI Report 1991, 193).

Due to these rebel attacks and violence among the Hutu and Tutsi in Rwanda, AI called on the Rwandan government to carry out fair trials and release prisoners of conscience (AI Report 1991, 1992, 1993). Additionally, AI published a report in 1992 entitled Rwanda: Persecution of Tutsi minority and repression of government critics, 1990 to 1992 and expressed its concerns to the UN Commission on Human Rights regarding the massive human rights violations taking place in Rwanda (AI Report 1993, 250). In 1993, an International Commission of Inquiry made up of

\footnotetext{
14 HRW is also referred to as Africa Watch.
} 
foreign NGOS visited Rwanda and confirmed these human rights abuses and “extrajudicial executions" (AI Report 1994, 251). Additionally, the UN Special Rapporteur and the UN Observer Mission to Uganda and Rwanda (UNOMUR) investigated the violence in Rwanda and confirmed previous reports regarding human rights violations (AI Report 1994, 252). Nevertheless, UNOMUR was "unable to determine who was responsible" (AI Report 1994, 252). AI also implored the RPF "to prevent deliberate and arbitrary killings of unarmed civilians and captured combatants and to respect human rights and basic humane standards" (AI Report 1994, 253). After the genocide, AI also noted that there was a huge refugee problem; camps were particularly dangerous and disease ran rampant (AI Report 1995, 27). In light of the 1994 Rwandan genocide, AI reflected on its efforts in its annual report from 1995 by citing a "special worldwide week of action focusing on the appalling human rights tragedies of Burundi and Rwanda" (11) and by emphasizing how AI "worked hard to bring to the world's attention the plight of the people in Burundi and Rwanda" through lobbying and media attention (AI Report 1995, 16). AI also used its report from 1995 to evaluate international action—or inactionduring the Rwandan genocide; the report stated that "there is no shortage of knowledge about impending human rights crises around the world. Amnesty International and other non-governmental organizations, independent UN experts and journalists all publicly document escalating human rights violations. The problem is the failure of governments and intergovernmental organizations to listen to these warnings and act quickly" (AI Report 1995, 34). AI also pointed out that the “UN'S own Special Rapporteur on extrajudicial executions visited Rwanda one year before the mass killings began, recommended that structures be set up to protect civilians from massacres," and "warned: lessons should be drawn from the past and the cycle of violence which has drenched both Burundi and Rwanda in blood ... the 
impunity of the perpetrators of the massacres must be definitively brought to an end and preventive measures to avoid the recurrence of such tragedies must be designed"' (AI Report 1995, 34). AI criticized the international community for not taking preventive and immediate measures to stop these killings (AI Report 1995, 34), "called on the international community to bear its share of the responsibility for the slaughter" (AI Report 1995, 252), and published Rwanda: Mass murder by government supporters and troops in April and May 1994 and Rwanda: Reports of killings and abductions by the Rwandese Patriotic Army, April to August 1994 that described the genocide as highly organized and planned (AI Report 1995, 252). Further, AI urged the international community to "[expand] international human rights monitoring; by sending UN civilian police monitors; by rebuilding Rwanda's judicial system; and by extending the jurisdiction of the international criminal tribunal established to deal with crimes against humanity in.. Rwanda" (AI Report 1995, 252).

Beginning in 1988, AI consistently published annual reports regarding the violence between the Hutu and the Tutsi. However, the reports largely mentioned the Hutu and the Tutsi skirmishes in isolation; most of the early reports cited the tensions in Burundi, but these tensions spilled over into Rwanda, which was not fully recognized. In other words, AI did not make an obvious connection between the two states. Thus, information politics was not fully utilized. By the time the violence spread and AI alerted regional and international organizations, the genocide was already in motion. Even once the violence started, AI was not completely comprehensive; in its 1995 report, it did not mention rape a single time. However, around 100,000 to 250,000 women were raped during the 1994 genocide (Outreach Programme 2016). Additionally, AI was critical of the international community for 
not reacting strongly to these atrocities, but the majority of these criticisms were published during and after the genocide, and thus did not serve their purpose. ${ }^{15}$ Human Rights Watch's Response

HRW started to monitor Rwanda in 1991(HRW Report 1992). HRW mentioned the 1991 massacre of the Tutsi by the "Rwandan police, military and civilian officials, along with ordinary citizens, " but also noted that while this massacre was talked about in Kigali, it was not mentioned by the media for several months; the Belgian newspaper L'Instant was the first to cover it (HRW Report 1992). Unfair trials and arrests were also the norm in Rwanda during this time (HRW Report 1992). As stated above, rape was used as a weapon of war in Rwanda, but HRW only mentioned rape once in its 1995 annual report on the genocide, thus minimizing a huge human rights violation that devastated the Rwandan population. Under HRW's US policy section, HRW conceded that the US had few economic or political interests in the region, but that in 1991, the Bush Administration "had several opportunities to raise human rights concerns with the Rwandan government, but did not always do so" (HRW Report 1992). Additionally, HRW mentioned that the US "privately encouraged Rwandan officials to increase respect for basic human rights and popular participation in the political process" (HRW Report 1992)— "privately” being the key word. HRW Report 1993 did not have a Rwanda section, but it did mention that the "peace agreement ... brought an end to the civil war in Rwanda." However, later events have shown that the civil war did not fully end in 1993. During 1993, HRW encouraged US Assistant Secretary of State George Moose

\footnotetext{
${ }^{15} \mathrm{AI}$ called on the UN to increase the number of observers and human rights monitors in Rwanda in May, which was one month into the killings (AI Report 1995, 36). Additionally, AI urged the international community in J uly to uphold human rights in Rwanda and Burundi (AI Report 1995, 85). In August of 1994, AI visited Rwanda to meet with local human rights groups (AI Report 1995, 252). Once again, these actions were too late.
} 
to start a dialogue with Rwandan President Habyarimana, when he came to visit the US, regarding human rights issues (HRW Report 1994). However, according to HRW, the US did not emphasize human rights in the talks with Habyarimana, "so as not to spoil the 'positive atmosphere' of the discussions"' (HRW Report 1994).

In various HRW reports, HRW referenced domestic NGOs and other international organizations that were active during the Rwandan civil war and subsequent genocide. In 1990, the Rwandan Association for the Defense of Human Rights (ARDHO) was created and started "actively investigating and documenting individual cases of human right abuse and intervening with Rwandan authorities" (HRW Report 1992). As of 1990, it had not released any reports but tried to draw attention to these atrocities via radio broadcasts (HRW Report 1992), which became problematic when the government had control of the radio (HRW Report 1992). HRW also mentioned five other organizations that were created in 1991 and played an active role in identifying and investigating the human rights violations in Rwanda: the Association of Volunteers of Peace (AVP), the Rwandan Association for the Defense of Human Rights and Public Liberties (ADL), Kanyarwanda, the Christian League for the Defense of Human Rights in Rwanda, and Society and Perspective (HRW Report 1992). These organizations took a variety of measures to bring attention to human rights abuses by recording testimonies of victims and collecting information of the killings, disappearances, and beatings (HRW Report 1992). In 1992, several local human rights groups in Rwanda proposed a plan to form an international investigatory commission on human rights; this commission, which became known as the International Commission of Investigation on Human Rights Violations in Rwanda, was composed of Africa Watch (HRW), the International Federation of Human Rights in Paris, and the Inter-African Union of Human Rights in Ouagadougou, and the International Center for Human Right and 
Democratic Development in Montreal (HRW Report 1994). This commission conducted interviews, collected details about the victims, and found that the Rwandan government was "guilty of serious and systematic human rights abuses" from October 1990 to J anuary 1993 (HRW Report 1994). HRW also worked on a lengthy report with the rest of the commission, outlining the results of the investigation (HRW Report 1994). Although this is a good example of "issue definition" and "issue adoption" where prominent international NGOs (HRW) and domestic NGOs work together to draw attention to human rights violations, the collaboration did not happen soon enough for it to be effective.

In its report from 1995 that reflected on the genocide from the previous year, HRW criticized the international community's inaction, with a specific focus on the US. According to HRW, the UN and the US "initially reacted with retreat, confusion, and lethargy" (HRW Report 1995). Further, HRW stated that the genocide "should have come as no surprise to the international community" (HRW Report 1995). While the US was active in establishing a ceasefire agreement, HRW claimed that the US did not have an "alternative plan of action" when the agreement failed to bring peace (HRW Report 1995). In reaction to the killings in Rwanda, HRW called for international recognition that the violence in Rwanda was in fact a genocide, encouraged a larger UN presence in Rwanda, urged the UN Human Rights Commission to conduct an investigation, and published a report called Genocide in Rwanda: April-May 1994 (HRW Report 1995). After the genocide, HRW sent a mission to Rwanda in August and October of 1994 (HRW Report).

Although HRW criticized the international community for its silence, most of the powerful "naming and shaming," leverage and accountability politics, took place during or after the genocide. As HRW explained, the genocide was imminent. If the genocide was so imminent and the racial tensions between the Hutu and the Tutsi so 
ancient, then one would have expected HRW "naming and shaming” to be intense long before the 1994. In reality, this did not occur.

Media Response

Matching the Kosovo case study, this case also uses the New York Times and CNN. 16 There were 952 New York Times articles that mentioned Rwanda from J anuary 1, 1986 to December 31, $1994 .{ }^{17}$ The amount of coverage varied throughout the years:

\begin{tabular}{|l|l|l|l|l|l|l|l|l|l|}
\hline Year & 198 & 198 & 198 & 198 & 199 & 199 & 199 & 199 & 199 \\
& 6 & 7 & 8 & 9 & 0 & 1 & 2 & 3 & 4 \\
\hline $\begin{array}{l}\text { Mentio } \\
\text { ns }\end{array}$ & 27 & 21 & 30 & 18 & 40 & 18 & 19 & 35 & 744 \\
\hline
\end{tabular}

Coverage in Rwanda was not sustained; most coverage took place in 1994 when the genocide was occurring. However, violence occurred long before 1994. After conducting an informal audit of the content of these news articles, the ones from 1986 did not focus on the ethnic conflicts in Rwanda and the surrounding area. ${ }^{18}$ Instead, they focused on the AIDS epidemic and the gorilla naturalist, Dian Fossey, who was murdered in Rwanda. The coverage in 1987 focused on AIDS, Dian Fossey, the poaching of gorillas in Rwanda, and safari trips to Rwanda. There were only one or two articles that mentioned ethnic unrest in 1987. In 1988, AIDS, gorillas, a Dian

\footnotetext{
16 The New York Times and CNN are highly regarded as credible sources of information, which is why they were used for this study. Nevertheless, it must be noted that there were many newspapers and networks that could have also played a role in information/ symbolic politics and guided the conversation about Rwanda in the US.

17 Data was retrieved from LexisNexis. Although "naming and shaming” took place as early as 1980, Lexis Nexis only has data from 1986 to the present. I chose the end date December 31, 1994 as the Rwandan genocide lasted until mid-1994.

18 I read all of the articles up to 1994 and used the titles as a guide.
} 
Fossey movie, tourism, and six stories about Burundi were mentioned. In 1989, there were no mentions of violence in Rwanda—only mentions of AIDS, wildlife adventures, gorillas, and agriculture. In 1990, news became more substantive; there were still several articles that focused on Dian Fossey, gorillas, and AIDS, but there were also ten articles that focused on the invasion and violence in Northern Rwanda. News articles in 1991 and 1992 were similar in content to 1990. Coverage on the refugee crisis and ethnic violence in Rwanda and the surrounding area became more substantive in 1993, but there were still several stories that focused on AIDS and tourism. By 1994, the majority of the stories focused on the killings and genocide in Rwanda. Additionally, between 1986 and 1994 there were 183 mentions of "human rights," six references of AI, and 24 references of HRW.

There were 571 mentions of Rwanda from CNN broadcast transcripts from J anuary 1, 1986 to December 31, 1994. ${ }^{19}$

\begin{tabular}{|l|l|l|l|l|l|l|l|l|l|}
\hline Year & 198 & 198 & 198 & 198 & 199 & 199 & 199 & 199 & 199 \\
6 & 7 & 8 & 9 & 0 & 1 & 2 & 3 & 4 \\
\hline $\begin{array}{l}\text { Mentio } \\
\text { ns }\end{array}$ & 0 & 0 & 0 & 0 & 0 & 3 & 0 & 11 & 557 \\
\hline
\end{tabular}

The CNN transcripts varied in content, with 143 transcripts mentioning "human rights" explicitly, 4 mentioning AI, and 10 mentioning HRW. There was not substantial coverage of Rwanda until 1994. None of the stories in 1991 had anything to do with the violence in Rwanda, but rather gorillas. In 1993, coverage focused on gorillas, UN action, and violence in Burundi and Rwanda. By 1994, coverage focused primarily on the killings.

19 Data was also retrieved from LexisNexis. 
International Response

The international community was convinced that the Arusha Accords, signed in 1993, were enough to end the civil war in Rwanda (HRW Report 1995). However, the violence resumed. The US took active steps to remove itself from the Rwanda situation; neither the US nor the UN would refer to the killings in Rwanda as a "genocide" for fear that it would require them to do something (HRW Report 1995). A New York Times article published in J anuary 1994 summed up their reactions well:

In a burst of compassion and amid loud applause, the United States a year ago rushed to the rescue of the sick and starving in Somalia. But for Africans, this holiday season is even bleaker, and not just for Somalis. When the humanitarian mission in Somalia went sour, most of Africa below the Sahara also seemed to drop from sight. Every bit of bad news -- civil wars, military coups, drought and disease -- has sadly reinforced a mood of fatalism or still worse, callous unconcern ("Africa, Out in the Cold" 1994, no author). ${ }^{20}$

The US refused to jam radio transmissions that could have interfered with the Hutu militia's systematic killing sprees and even helped the UN remove troops from Rwanda during the genocide (HRW Report 1995). ${ }^{21}$ In short, the international community did not respond, with any haste, to the situation in Rwanda. Success of NGO "Naming and Shaming”

\footnotetext{
${ }^{20}$ Additionally, no US Gallup polls were conducted about Rwanda, so it is unclear how Americans felt about the genocide.

${ }^{21}$ Apparently, members of Congress "expressed their concern" about the killings in Rwanda and in April 1994, the Senate passed a resolution that denounced the killings (HRW Report 1995). However, I could not find any of these transcripts or bills on congress.gov.
} 
Although all types of NGO "naming and shaming" were present during the conflict in Rwanda, it was not sustained or comprehensive. Information and Symbolic Politics

Although AI provided annual reports about Rwanda, research was scattered and regional instability was not emphasized. HRW did not have a mission set up in Rwanda until 1991. By that time, violence was dangerously evident. Although there were a number of domestic NGOs in Rwanda, they were not able to successfully communicate their findings quickly; once the genocide started, it was chaotic and difficult to communicate. The New York Times and CNN provided some coverage about Rwanda, but it was largely concentrated in 1994. During the years prior to 1994, coverage was sparse. These news outlets seemed more concerned about gorillas and safaris in Rwanda than the violence taking place. It is also interesting that some important facts about the Rwandan genocide are still unknown. For example, there is still not an accurate estimate of how many people were killed. Leverage and Accountability Politics

Leverage and accountability politics can be used interchangeably. Although AI and HRW condemned the international community for doing nothing, most of the condemnations occurred during and after the genocide. For leverage and accountability politics to be effective, the timing matters. AI and HRW both knew that a genocide was imminent, but they did not fully utilize this information in a quick manner, based on their annual reports.

Result: No Response

The Rwandan conflict did not elicit a strong international response. NGO "naming and shaming" during the conflict in Rwanda was substantial in number, but not in quality or in sustained effort. In other words, it was not comprehensive as it did not occur fast enough or deliberately enough over the long term. Additionally, in 
the case of Rwanda, there was a disconnect between domestic NGOs and international NGOs like AI and HRW in relaying information. While there appeared to be a large mobilization of domestic NGOs in Rwanda, the mobilization was not quick enough (issue definition) and AI and HRW were unable to adopt the issue (human rights violations in Rwanda) in a timely and complete manner.

\section{A Comparison of Rwanda and Kosovo}

Applying the hypothesis

While Murdie and Peksen's (2013) quantitative research found a connection between NGO "naming and shaming" and humanitarian intervention, this paper describes the nature of this relationship through a comparative case study, using the previously stated hypothesis: The more comprehensive a NGO's "naming and shaming" campaigns are in a particular state in regards to a humanitarian issue, the more likely an outside state will intervene in that target country. NGO "naming and shaming" was much more comprehensive in Kosovo than in Rwanda. AI and HRW discussed the Kosovo conflict in detail, while information regarding Rwanda was disjointed and incomplete. Further, the Kosovo conflict was covered more often and with more substance in the New York Times and on CNN than the conflict and genocide in Rwanda. Although AI and HRW condemned the international community for not reacting to the Rwandan genocide, their condemnations were too late as the genocide was already in motion.

Given the results of these two cases, there is a strong relationship between the quality of "naming and shaming" and the likelihood of intervention. Additionally, a large quantity of NGO "naming and shaming" does not always elicit a strong international response; once AI, HRW, the New York Times, and CNN decided to focus on Rwanda, there was a lot of coverage. However, NGO "naming and shaming" campaigns must be more than substantial in number, they have to be strategic. 
Kosovo "naming and shaming" campaigns were sustained and substantive, while Rwanda "naming and shaming" campaigns were delayed and frequently incomplete. States and human rights NGOs often view the Rwandan genocide as a failure of state governments to act, but perhaps it was a failure of humanity as a whole to act. Human rights NGOs like AI and HRW attempted to fight for Rwanda, but they started the fight too late.

Finally, NGO "naming and shaming" influences the likelihood of humanitarian intervention, but it is only a piece of the puzzle; there are many factors that prompt a state to intervene or not to intervene. Nevertheless, it is important to acknowledge that NGO "naming and shaming" can activate certain actions or make certain topics salient.

External Factors

Some external factors that might have also contributed to state intervention or non-intervention in Kosovo and Rwanda were the length of the conflict, the geography, and the chronology of international events.

There is an argument that the Kosovo conflict lasted longer and was therefore was more conducive to "naming and shaming" than the Rwandan genocide. However, violence between the Hutu and the Tutsi dates back to the 1960s (Power 2002, 336). In 1990, ethnic tensions were heightened as the RPF invaded Rwanda (Power 2002, 336). Further, there were hints that violence was about to occur: "in August 1993 a radio station ... had begun broadcasting ever more dramatic incitements to hatred and killing[,]" and there were "increasing numbers of unemployed young men" joining "exclusively Hutu militias" (HRW Report 1995). In short, conflicts rarely begin out of nowhere; both the Kosovo and Rwandan conflicts were deeply rooted in the past. 
Geography can also affect a state's decision to intervene. Kosovo is located in Europe, while Rwanda is located in central Africa. The US has always been heavily tied to Europe economically and politically, which might have influenced its decision to intervene in Kosovo. Africa, on the other hand, is less of a focus for the US. Although this argument is certainly sound, there seems to be a disconnect between American rhetoric and action. For example, if President Bill Clinton can ignore the genocide in Rwanda and yet claim that "America, as the world's superpower, ought to be standing up against ethnic cleansing" in the case of Kosovo, then there seems to be a deadly flaw in American reasoning (J ackson 2006, 149). Additionally, Clinton claimed that the US was going to restore "freedom and stability in Europe" (J ackson 2006, 147). The Kosovo conflict certainly represented regional instability in Yugoslavia as a whole, but the Rwanda case also represented instability in central Africa. The conflict was not confined to just one small country; Burundi, Zaire, Tanzania, Uganda, and many other states were also negatively affected by the fighting between the Hutu and the Tutsi, not to mention the huge number of people who were displaced due to the violence (AI Reports 1988-1994, HRW Reports 19921995).

Another compelling argument that could help explain the likelihood of intervention is the chronology. The Rwandan genocide occurred directly after the failed intervention in Somalia ("Africa, Out in the Cold"), while the Kosovo intervention occurred right after the failure to intervene in Rwanda. However, violence between the Hutu and the Tutsi started long before the international failure in Somalia (Power 2002, 336). Additionally, although the decision to intervene in Kosovo was no doubt influenced by the inaction in Rwanda, one would expect that future decisions to intervene would also be influenced by the shame of not intervening in situations like Rwanda. However, the US is still choosing not to 
intervene in countries like the Central African Republic that are plagued by severe human rights abuses, which suggests that chronology is not the only factor to consider.

State Reputation and Public Opinion

This paper posits that states that value international reputation are more likely to intervene than states that do not value international reputation. In the case of Kosovo, the US projected the image of a powerful state by negotiating with other parties and communicating with NATO. Further, American rhetoric from highranking officials confirmed the US desire to maintain and uphold its reputation as a world power. Likewise, theinaction by the USin Rwanda actually reinforced this value of remaining a superpower. The US did not want to intervene in Rwanda because it did not want to suffer the embarrassment and pain of another failed humanitarian mission like the one in Somalia. Intervention in Rwanda would not have been expensive per se, but the cost of failure and American lives might have been too great. Perhaps if NGOs had presented more attainable solutions to ending or preventing the genocide in Rwanda, the US would have reacted differently. However, there is never a flawless plan. Still, the US not only failed to intervene, but also failed to provide any support-even basic aid like jamming radio transmissions, which would not have required military intervention. Nevertheless, the US did not observe any domestic support to intervene, which further solidified its decision.

It was difficult to measure how much domestic opinion influences a state's decision to intervene, as the Kosovo conflict was the only case that had public opinion polls available. This represents a possible weakness in the internationalist argument. Nevertheless, while domestic opinion on Kosovo was not necessarily consistent, public opinion polls suggest that American citizens were generally in favor of the US maintaining its prominent role in the international community. Alas, the peak of the 
Rwandan genocide was so quick and largely unnoticed by the American public that US public opinion polls were not conducted.

\section{Conclusions}

Looking forward, future research could include more contemporary cases where human rights NGOs utilized technology (social media, the Internet, etc.) to influence state decision making. It would also be advantageous to gather more information on domestic NGOs and a comprehensive list of hearings and testimonies from AI and HRW. Another interesting continuation of this project would be to evaluate the motivations of human rights NGOs to "name and shame." One would expect that NGOs would "name and shame" the majority of the time, but as shown through the Rwanda case, even human rights organizations can fall short when fighting for human rights.

Cosmopolitans claim that states should act out of altruism, while realists argue that states are motivated by strategic interests alone. In the case of Kosovo and Rwanda, the internationalist view serves as a useful guide to better evaluate the role of international norms and non-state actors. The rise of intrastate conflicts and the devastating effects of human rights violations not only make this topic relevant, but also urgent. Humanitarian concerns will only increase, and the international community will have to grapple with R2P and its ever-ambiguous call to defend the population of a state that fails to protect its own citizens. 


\section{References}

Adelman, Howard. Early Warning and "Ethnic" Conflict Management: Rwanda and Kosovo. Refuge, Vol. 18, No. 3 (Aug., 1999): pp. 5-9. Web. 4 Nov. 2014.

Amnesty International. Amnesty International Reports 1981-2000. London: Amnesty International Publications. Print.

Amnesty International. 2016. “Who We Are.” Accessed February 2, 2016. https:// www.amnesty.org/ en/ who-we-are/ .

Auerswald, Philip and Auerswald, David. 2000. The Kosovo Conflict: A Diplomatic History Through Documents. The Hague: Kluwer Law International. Print.

Bellamy, Alex J. The Responsibility to Protect and the Problem of Military Intervention. International Affairs (Royal Institute of International Affairs 1944-), Vol. 84, No. 4 (Jul., 2008): pp. 615-639. http:/ / www.jstor.org/ stable/ 25144868.

Bellamy, Alex J. The Responsibility to Protect-Five Years On. Ethics \& International Affairs, Vol. 24, No. 2 (2010): 143- 169. Web. 4 Nov. 2014.

Carpenter, Charli. Setting the Advocacy Agenda: Theorizing Issue Emergence and Nonemergence in Transnational Advocacy Networks. International Studies Quarterly, Vol. 51, No. 1(Mar., 2007): pp. 99-120. http:/ / www.jstor.org/ stable/ 4621703. 
Davis, David R.; Murdie, Amanda; Steinmetz; Coty Garnett. "Makers and Shapers": Human Rights INGOs and Public Opinion. Human Rights Quarterly, Vol. 34, No. 1(Feb., 2012): pp. 199-224. Web. 4 Nov. 2014.

Donnelly, J ack. Human rights, humanitarian crisis, and humanitarian intervention. International J ournal, Vol. 48, No. 4, Humane intervention (AUTUMN 1993): pp. 607-640.

http:/ / www.jstor.org/ stable/ 25734034.

Drury, A. Cooper; Olson, Richard Stuart; Van Belle, Douglas A. The Politics of Humanitarian Aid: U.S. Foreign Disaster Assistance, 1964-1995. The J ournal of Politics, Vol. 67, No. 2 (May, 2005): pp. 454-473. http:// www.jstor.org/ stable/ 3449639.

Finnemore, Martha and Sikkink, Kathryn. International Norm Dynamics and Political Change. International Organization, Vol. 52, No. 4, International Organization at Fifty: Exploration and Contestation in the Study of World Politics (Autumn, 1998): pp. 887-917. http:// www.jstor.org/ stable/2601361.

Fixdal, Mona and Smith, Dan. Humanitarian Intervention and J ust War. Mershon International Studies Review, Vol. 42, No. 2 (Nov., 1998): pp. 283-312. http:// www.jstor.org/ stable/ 254418.

Gent, Stephen E. Strange Bedfellows: The Strategic Dynamics of Major Power Military Interventions. The J ournal of Politics, Vol. 69, No. 4 (Nov., 2007): pp. 1089-1102. http:// www.jstor.org/ stable/ 4622616. 
Gibbs, David. "Realpolitik and Humanitarian Intervention." International Politics 37 (n.d.): pp. 41-55. University of Arizona. Web. 15 Oct. 2014. http:// dgibbs.faculty.arizona.edu/ sites/ dgibbs.faculty.arizona.edu/files/ som alia.pdf.

Greenwood, Christopher. Is There a Right of Humanitarian Intervention? The World Today, Vol. 49, No. 2 (Feb., 1993): pp. 34-40. http:/ / www.jstor.org/ stable/ 40396480.

Hafner-Burton, Emilie M. Sticks and Stones: Naming and Shaming the Human Rights Enforcement Problem. International Organization, Vol. 62, No. 4 (Fall, 2008): pp. 689-716. http:// www.jstor.org/ stable/ 40071894.

Hearing on the Kosova Peace, Democracy, and Human Rights Act of 1995Extensions of Remarks, House of Representatives, March 31, 1995 (Testimony of Eliot Engel).

Hearing on the Repression and Violence in Kosovo, US Helsinki Commission, March 18, 1998 (Testimony of Fred Abrahams).

Hearing on Yugoslavia, Senate, J une 28, 1990 (Testimony of Alfonse D'Amato).

Hearing Regarding Albanian Minorities in Yugoslavia, House of Representatives, October 22, 1990 (Testimony of Benjamin Gilman).

Human Rights Watch. Human Rights Watch Reports 1989-2000. New York: Human Rights Watch Publications. Print. 
Human Rights Watch. 2016. "About Our Research.” Accessed February 2, 2016. https:// www.hrw.org/ about-our-research.

Jackson, Patrick Thaddeus. 2006. “Relational Constructivism: A War of Words.” In Making Sense of International Relations Theory, ed. J ennifer Sterling-Folker. United States of America: Lynne Rienner Publishers, 139-156. Print.

Keck, Margaret E. and Sikkink, Kathryn. Activists beyond Borders: Advocacy Networks in International Politics. Ithaca and London: Cornell University Press, 1998. Print.

Kllokoqi, Selatin; Ahmeti, Blerim; Konjufca, Glauk; Murati, Valon. Country Specific Report: Conflict Settlement Agreement Kosova. MIRICO: Human and Minority Rights in the Life Cycle of Ethnic Conflicts; Sixth Framework Programme; University of Pristina, September 2007. Web. 4 Dec. 2014.

Lampe, J ohn. 2015. “Bosnian Conflict.” Encyclopedia Britannica, 2016. Web. Accessed February 20, 2016. http:/ / www.britannica.com/ event/ Bosnianconflict.

Lebovic, J ames H. and Voeten, Erik. The Politics of Shame: The Condemnation of Country Human Rights Practices in the UNCHR. International Studies Quarterly, Vol. 50, No. 4 (Dec., 2006): pp. 861-888. http:// www.jstor.org/ stable/ 4092783.

Meernik, J ames; Aloisi, Rosa; Sowell, Marsha; Nichols, Angela. The Impact of Human Rights Organizations on Naming and Shaming Campaigns. The J ournal of Conflict Resolution, Vol. 56, No. 2 (Apr., 2012): pp. 233-256. Web. 1Nov. 2014. 
http:// www.polisci.wisc.edu/Uploads/ Documents/ IRC/ Meernik\%20et\%20al .pdf.

Morgenthau, Hans J . Another "Great Debate": The National Interest of the United States. The American Political Science Review, Vol. 46, No. 4 (Dec., 1952): pp. 961-988. http:// www.jstor.org/ stable/ 1952108.

Murdie, Amanda, and Dursun Peksen. 2013. “The Impact of Human Rights INGO Shaming on Humanitarian Interventions." The J ournal of Politics 76 (1): pp. 215-228. http:/ / www.jstor.org/ stable/ 10.1017/ s0022381613001242 (Accessed November 1, 2014).

Musoni, Edwin. "Rwanda: Report Claims 2 Million Killed in 1994 Genocide.” 4 October 2008. AllAfrica: 2014. < http:/ / allafrica.com/ stories/200810040044.html.

Pastor, Robert. Forward to the beginning: widening the scope for global collective action. International J ournal, Vol. 48, No. 4, Humane intervention (AUTUMN 1993): pp. 641-667. http:// www.jstor.org/ stable/ 25734035.

Outreach Programme on the Rwanda Genocide and the United Nations. “Background Information on Sexual Violence used as a Tool of War" United Nations, 2016.

http:// www.un.org/ en/ preventgenocide/ rwanda/ about/ bgsexualviolence.sht $\mathrm{ml}$.

Pearson, Frederic S., and Robert A. Baumann. 1993. “International Military Intervention, 1946-1988." Inter-University Consortium for Political and Social Research, Data Collection No 6035, University of Michigan, Ann Arbor. 
Power, Samantha. 2002. A Problem From Hell: America and the Age of Genocide. New York: Basic Books. Print.

Risse, Thomas; Ropp, Stephen C.; Sikkink, Kathryn. The Power of Human Rights: International Norms and Domestic Change. Cambridge: Cambridge University Press, 1999. Print.

Saad, Lydia. 1999. “Americans Hesitant, As Usual, About U.S. Military Action in Balkans." Gallup, 2016. Web. Accessed February 10, 2016. http:// www.gallup.com/ poll/3994/Americans-Hesitant-Usual-About-USMilitary-ActionBalkans.aspx?g_source=Kosovo\%20conflict\&g_medium=search\&g_campaig $\mathrm{n}=$ tiles.

Saad, Lydia, 1999. “Kosovo Intervention Hasn't Shaken Americans' Basic World View." Gallup, 2016. Web. Accessed February 10, 2016. http:// www.gallup.com/poll/3760/ Kosovo-Intervention-Hasnt-ShakenAmericans-Basic-WorldView.aspx?g_source=Kosovo\%20conflict\&g_medium $=$ search\&g_campaign $=t$ iles.

S.Con.Res.33 - A concurrent resolution expressing the sense of Congress regarding the need for vigorous prosecution of war crimes, genocide, and crimes against humanity in the former Republic of Yugoslavia, 106th Congress (1999-2000).

S.Con.Res.85 - A concurrent resolution calling for an end to the violent repression of the people of Kosovo, 105th Congress (1997-1998). 
S.1347 - International Security and Development Cooperation Act of 1989, 101st Congress (1989-1990).

Walzer, Michael. J ust and Unjust Wars: A Moral Argument with Historical Illustrations. New York: Basic Books, 1977. Print.

Weiss, Thomas G. The Sunset of Humanitarian Intervention? The Responsibility to Protect in a Unipolar Era. Security Dialogue. Vol. 35, No. 2 (J un., 2004): pp. 135-153. http:// sdi.sagepub.com/ content/ 35/2/ 135. 